\title{
PENGARUH MODEL PETA PIKIRAN TERHADAP \\ KEMAMPUAN MENULIS TEKS PIDATO OLEH \\ SISWA KELAS IX SMP NEGERI 17 MEDAN \\ TAHUN PEMBELJARAN \\ 2016/2017

\author{
Oleh \\ Winda Purnama Sari Hasibuan \\ Dra. Inayah Hanum, M.Pd.
}

\begin{abstract}
Abstrak
Penelitian ini bertujuan untuk mengetahui pengaruh penggunaan model peta pikiran terhadap kemampuan menulis teks pidato oleh siswa kelas IX SMP Negeri 17 Medan Tahun Pembelajaran 2016/2017. Populasi penelitian ini adalah seluruh siswa kelas IX SMP Negeri 17 Medan sebanyak 218 orang. Metode dalam penelitian ini adalah metode eksperimen dengan desain one group pre-test post-test. Instrumen yang digunakan adalah tes essai. Dari pengolahan data diperoleh nilai rata-rata pre-test $=64,37$, standar deviasi $=7,88$, dan termasuk kategori sangat baik sebanyak 0 orang atau $0 \%$, kategori baik sebanyak 13 siswa atau 40,62\%, kategori cukup sebanyak 16 orang atau $50 \%$, kategori. Nilai rata-rata post-test $=81,09 \%$, standar deviasi $=7,04$, dan termasuk kategori sangat baik sebanyak 15 orang atau $46,87 \%$, kategori baik sebanyak 15 orang atau 46,87 \%, kategori cukup sebanyak 2 orang atau 6,25\%. Berdasarkan uji normalitas, hasil pret-test dan post-test dinyatakan dalam distribusi normal. Kemudian, berdasarkan uji homogenitas dinyatakan bahwa sampel berasal dari populasi yang homogen. Setelah uji normalitas dan homogenitas, didapatlah $t_{o}$ sebesar 7,15 dengan tabel t pada taraf signifikan 5\% dengan $\mathrm{df}=\mathrm{N}-1=32-1=31$ diperoleh nilai $t_{\text {tabel }} 8,00$. Hasil tersebut menunjukkan nilai $t_{\text {hitung }}$ yaitu $6,26>$ 2.04, maka hipotesis nihil (Ho) ditolak dan hipotesis alternatif (Ha) diterima. Berdasarkan analisis data dapat disimpulkan bahwa terdapat pengaruh yang signifikan atas penggunaan model peta pikiran terhadap kemampuan menulis teks pidato oleh siswa kelas IX SMP Negeri 17 Medan Tahun Pembelajaran $2016 / 2017$.
\end{abstract}

Kata Kunci: model peta pikiran, menulis teks pidato.

\section{PENDAHULUAN}

Bahasa merupakan alat komunikasi, baik komunikasi secara lisan maupun tertulis. Pengajaran bahasa tentunya harus dapat mengembangkan keterampilan berbahasa siswa. Keterampilan berbahasa pada dasarnya merupakan satu kesatuan. Keterampilan berbahasa pada dasarnya merupakan satu kesatuan. 
Menurut pendapat Tarigan (2008:1) menyatakan bahwa keterampilan berbahasa mencakup empat jenis yaitu keterampilan menyimak (Listening Skill), Keterampilan berbicara (Speaking skill), Keterampilan membaca (Reading skill), dan keterampilan menulis (Writing skill). Keempat keterampilan tersebut saling terkait antara satu dengan yang lain.

Menurut pendapat Ernawati, (2013:546) mengatakan bahwa menulis teks pidato pada hakikatnya menuangkan gagasan ke dalam bentuk bahasa tulis yang siap dilisankan. Pilihan kalimat, paragraf, dalam menulis sebuah pidato sesungguhnya tidak jauh berbeda dengan kegiatan menulis naskahyang lain.

Kemudian, Akhadiah (1996, dalam Ernawati,2013:546) secara lebih spesifik menjelaskan bahwa masalah yang sering dilontarkan dalam pelajaran tulis-menulis masih banyaknya permasalahan yang dihadapi siswa, misalnya: siswa kurang mampu menggunakan bahasa Indonesia dengan baik dan benar. Hal tersebut dapat dilihat dari pilihan kata yang kurangtepat, kalimat yang kurang efektif, sukar mengungkapkan gagasan karenakesulitan memilih kata atau membuat kalimat, bahkan kurang mampu mengembangkan ide secara teraturdan sistematis, di samping kesalahan masalahejaan.

Berdasarkan hasil pengamatan pengajaran bahasa Indonesia di SMP Negeri 17 Medan ditemukan beberapa kelemahan diantaranya adalah hasil belajar bahasa Indonesia tentang materi kemampuan menulis teks pidato yang dicapai siswa masih rendah. Fakta tersebut ditunjukkan oleh nilai rata-rata hasil belajar bahasa Indonesia adalah 60, dan hal ini berarti masih dibawah kriteria ketuntasan minimal (KKM) seperti yang ditetapkan oleh sekolah yang bersangkutan yaitu 75 .

Dalam Kurikulum Tingkat Satuan Pendidikan (KTSP) guru diharapkan lebih aktif dan kreatif dalam pembelajaran. Penerapan metode pembelajaran diharapkan lebih bervariatif sehingga menciptakan pembelajaran yang menyenangkan maka akan tercipta proses transfer pengetahuan pada diri siswa secara alami melalui pengalaman nyata atau kontekstual. Karena penggunaan metode dan teknik yang salah akan menyebabkan siswa cenderung tidak berminat untuk menulis, untuk menanggulangi permasalahan yang timbul karena kurang efektifnya metode dan teknik dalam pembelajaran menulis teks pidato hendaknya guru lebih inovatif dalam menyampaikan materi, tidak hanya dilakukan dengan ceramah atau mencatat, tetapi juga melalui 
pembelajaran dengan mengaktifkan dan mengikut sertakan siswa di dalam kelas, untuk itu perlu dilakukan hal baru yang salah satunya adalah dengan metode peta konsep. Dengan demikian penggunaan model pembelajaran peta pikiran bukanlah hanya sebagai alat bantu tetapi juga membantu penafsiran siswa tentang objek yang meraka amati. Dengan model Peta Pikiran siswa sevara khusus diharapkan untuk lebih efektif dan mampu terhadap kemampuan menulis teks pidato.

\section{METODE PENELITIAN}

Metode yang digunakan dalam penelitian ini adalah metode yang sesuai dengan masalah dan tujuan penelitian yaitu metode eksperimen. Penelitian eksperimen merupakan penelitian yang dimaksudkan untuk mengetahui ada tidaknya akibat dari 'sesuatu' yang dikenakan pada subjek selidik". Dengan kata lain, penelitian eksperimen mencoba meneliti ada tidaknya pengaruh dari suatu perlakuan dengan model peta pikiran yaitu tanpa menggunakan kelompok pembanding. Metode ini digunakan untuk mengetahui pengaruh model pembelajaran peta pikiran terhadap kemampuan menulis teks pidato siswa kelas IX SMP Negeri 17 Medan tahun pembelajaran 2016/2017.

Data yang diperoleh selanjutnya dianalisis secara statistik dengan langkahlangkah analisis yaitu data hasil pre-test dan post-test disusun dalam bentuk tabel, menentukan nilai rata-rata dan standar deviasi dari kedua data sampel, menghitung uji normalitas, uji homogenitas, dan uji hipotesis. Setelah to diketahui maka nilai tersebut akan dikonsultasikan dengan tabel pada taraf signifikansi $5 \%$ dengan derajat kebebasan $(\mathrm{dk})=\mathrm{n}-1$ pada taraf nyata $\alpha=0,05$. Dengan demikian, jika $t_{\mathrm{o}}<\mathrm{t}_{\mathrm{t}}$ pada taraf nyata $\alpha=0,05$ maka Ho diterima dan Ha ditolak sebaliknya jika $\mathrm{t}_{\mathrm{o}}>\mathrm{t}_{\mathrm{t}}$ pada taraf nyata $\alpha=0,05$ maka Ho ditolak dan Ha diterima. 


\section{HASIL PENELITIAN}

Setelah diadakan penelitian dan data sudah terkumpul, langkah selanjutnya adalah menganalisis data. Penelitian ini berupa eksperimen yaitu menggunakan one group pre-test post-test, pengambilan data dilakukan dua kali terhadap kelas yang sama. Pertama pre-test adalah pengambilan data sebelum menerapkan model peta pikiran.Kedua adalah post-test yaitu pengambilan data setelah menerapkan model peta pikiran. Data yang diperoleh adalah kemampuan menulis pidato siswa kelas IX SMP Negeri 17 Medan tahun pembelajaran 2016/2017.Dengan jumlah sampel dalam penelitian ini sebanyak 32 orang.Berikut data hasil pre-test dan post-test siswa.

\section{a. Deskripsi Data Kemampuan Menulis Teks Pidato Sebelum Menerapkan Model Peta Pikiran \\ Keterampilan menulis pidato sebelum menggunakan model pembelajaran} peta pikiran terhadap 32 siswa yang menjadi sampel maka, diperoleh rentang nilai 50-75. Nilai rata-rata dari akumulasi nilai keseluruhan tersebut adalah sebesar 64,37 tergolong pada kategori cukup.

\section{b. Deskripsin Data Kemampuan Menulis Teks Pidato Setelah Menerapkan Model Pembelajaran Peta Pikiran}

Keterampilan menulis pidato sebelum menggunakan model pembelajaran peta pikiran terhadap 32 siswa yang menjadi sampel maka, diperoleh rentang nilai 6580.Nilai rata-rata dari akumulasi nilai keseluruhan tersebut adalah sebesar 81,09 tergolong pada kategori cukup.

\section{PEMBAHASAN HASIL PENELITIAN}

Berdasarkan aspek penilaian keterampilan menulis dalam menulis teks pidato yang telah dibahas sebelumnya, hasil belajar siswa dalam menulis teks pidato termasuk dalam kategori kurang karena berada pada rata-rata 64,37. Berdasarkan KKM (Kriteria Ketuntasan Minimal), nilai rata-rata siswa termasuk kategori tidak tuntas karena berada di bawah nilai 75. Hal tersebut dapat dilihat dari frekuensi penilaian di mana jumlah siswa lebih banyak masuk ke dalam kategori kurang sebesar 9,37\%. Dari data tersebut pula diperoleh standar deviasi 
yaitu sebesar 7,88 dan standar eror sebesar 1,41. Sedangkan datanya berdistribusi normal dengan $l_{\text {hitung }}<l_{\text {tabel }}$ yakni $0,115<0,156$.

a. Kemampuan menulis teks pidato sebelum menerapkan model peta pikiran adalah mendapat kategori kurang atau tidak tuntas dan belum termasuk ke dalam kategori sangat baik.

Rendahnya kemampuan menulis teks pidato juga didukung oleh penelitian yang dilakukan Ridha Herdiani (2013:2) dalam jurnalnya yang berjudul "Model Pembelajaran Menulis Teks Pidato Dengan menggunakan Teknik Sinektik Terhadap Siswa Kelas X 5 SMA Tanjungsari Kecamatan Tanjungsari” menyatakan," kemampuan siswa dalam menulis pidato khususnya di SMA Tanjungsari masih jauh dari harapan. Keterbatasan wawasan, pengetahuan, dan keingintahuan guru sebagai pelaksana kurikulum belum dapat memvariasikan metode, dan teknik pembelajaran yang bertumbu pada PAKEM.

Siswa sebagai subjek dianggap sebagai objek sehinga kreatifitasnya terbatasi pada suatu teknik yang diatur oleh guru. Sejalan dengan itu, Siti Rahmah (2012:3) dalam jurnalnya yang berjudul"'Model Pembelajaran Menulis Teks Pidato Dengan Menggunakan Tekhnik Berpikir-Berpesangan-Berempat (ThinkPair-Square) di Kelas VIII SMP Tutwuri Handayani Cimahi Tahun Pembelajaran 2011/2012" menyatakan bahwa, Banyak guru yang menggunakan cara lama tata cara pendekatan tradisional dalam mengajarkan berbicara atau mengarang. Jadi para guru tersebut belum menerapkan kurikulum 2006 yang menyebutkan bahwa tujuan keterampilan berbicara adalah bahwa setiap siswa mampu berpidato secara efektif dan efisien dala berbagai jenis berbicara dalam berbagai konteks serta mengapresiasi karya sastra dala berbagai jenis dan bentuk melalui kegiatan berpidato. Rendahnya hasil belajar siswa dalam menulis teks pidato ini disebabkan guru yang mengajarkan kemampuan menulis umumnya jarang menggunakan model pembelajaran yang menarik minat siswa dan cenderung menjelaskan melalui model ceramah. Hal ini membuat siswa sulit untuk menuangkan ide ke dalam bentuk tulisan serta merangkai kalimat demi kalimat menjadi sebuah teks yang utuh. Sehingga siswa menjadi jenuh dan minat menulis pun rendah. Pada tahap sebelum penerapan model peta pikiran ini siswa berlatih 
untuk meningkatkan kemampuan menulisnya hanya dengan menuliskan apa yang mereka tahu saja tanpa diberikan arahan yang menarik siswa untuk berpikir secara logis dan sistematis.

Berdasarkan aspek penilaian keterampilan menulis dalam menulis teks pidato yang telah dibahas sebelumnya, hasil belajar siswa dalam menulis teks pidato termasuk dalam kategori baik karena berada pada rata-rata 81,09. Berdasarkan KKM (Kriteria Ketuntasan Minimal), nilai rata-rata siswa termasuk kategori tidak tuntas karena berada di bawah nilai 75. Hal tersebut dapat dilihat dari frekuensi penilaian di mana jumlah siswa lebih banyak masuk ke dalam kategori baik sebesar 46,87\%. Dari data tersebut pula diperoleh standar deviasi yaitu sebesar 7,04, dan standar eror sebesar 1,26. Sedangkan datanya berdistribusi normal dengan $l_{\text {hitung }}<l_{\text {tabel }}$ yakni $0,115<0,156$.

b. Kemampuan menulis teks berita setelah menerapkan model Peta pikiran mendapat kategori baik atau tuntas.

Hal ini disebabkan karena setelah penggunaan model Peta Pikiran siswa merasa tertarik dalam menulis teks berita karena disuguhkan sebuah model yang isinya mencari pidato sendiri, memaparkan bukti dan menulis sebuah teks berdasarkan bukt tersebut. Model Peta Pikiran dapat memberikan stimulus kepada siswa untuk merangsang pikiran, perasaan, perhatian, dan minat siswa dalam proses belajar khususnya dalam kemampuan menulis teks pidato. Penggunaan model peta pikiran dalam pembelajaran menulis teks berita ini dimaksudkan agar siswa mampu aktif untuk menggali ide, gagasan dan pikirannya untuk membuat sebuah teks pidato.

Meningkatnya kemampuan siswa dalam menulis teks pidato juga didukung dengan hasil penelitian yang dilakukan oleh Gusti Ngurah Oka Agustawan (2014:5) dalam jurnalnya yang berjudul "Penggunaan Teknik Peta Pikiran Untuk Meningkatkan Kemampuan Siswa Dalam Menentukan Fakta Dan Opini Pada Tajuk Rencana Bali Post Di Kelas Xi Ipa 2 Sma Negeri 1 Sawan”. Hasil penelitian ini diketahui Ada tiga temuan penting dalam penelitian ini, yaitu (1) tercapainya peningkatan dan ketuntasan hasil belajar menentukan fakta dan opini siswa kelas XI IPA 2 SMA Negeri 1 Sawan dengan penggunaan teknik mind 
mapping, (2) pembelajaran menentukan fakta dan opini dengan menggunakan teknik peta pikiran mampu meningkatkan aktivitas belajar mengajar yang berupa interaksi antar warga belajar (3) meningkatnya respons siswa terhadap penggunaan teknik peta pikiran.

Sejalan dengan itu, Rappel Situmorang (2013: 26) dalam jurnalnya yang berjudul "Pengaruh Metode Peta Pikiran Terhadap Hasil Belajar Siswa Pada Materi Suhu Dan Kalor Di Sma Negeri 2 Tebing Tinggi" menyatakan, "Rata- rata hasil belajar siswa pada kelas eksperimen yang diberi perlakuan dengan metode peta pikiran adalah 74,9 yang tergolong baik. Nilai rata- rata hasil belajar siswa pada kelas kontrol yang diberi perlakuan dengan metode konvensional adalah 64,2 yang tergolong cukup. Ada pengaruh yang signifikan menggunakan metode peta pikiran terhadap hasil belajar siswa pada materi Suhu dan Kalor di kelas XSMA Negeri 2 Tebing Tinggi. Aktivitas belajar siswa yang diamati pada penerapan pembelajaran metode peta pikiran mengalami peningkatan dari pertemuan I sampai pertemuan II dengan nilai rata-rata sebesar 71,2 termasuk kategori aktif.

Dengan demikian hal ini jelas bahwasannya model peta pikiran adalah model pembelajaran yang sangat efektif yang dapat digunakan guru dalam menyampaikan materi ajarnya kepada siswa. model pembelajaran peta pikiran adalah model pembelajaran yang memahami konsep, arti, dan hubungan melalui proses inisiatif untuk sampai kepada satu kesimpulan. Dengan teknik tersebut, siswa dibiarkan menemukan sendiri atau mengalami proses mental sendiri sedangkan guru hanya membimbing dan memberikan instruksi. Menteri atau bahan pelajaran yang akan disampaikan tidak disampaikan dalam bentuk final, akan tetapi siswa didorong untuk mengidentifikasi apa yang ingin diketahui kemudian dilanjutkan dengan mencari informasi sendiri, lalu mengorganisasikan atau membentuk apa yang mereka ketahui dan mereka pahami dalam suatu bentuk akhir. Sehingga dengan penerapan model ini siswa menjadi lebih paham dan bersemangat dalam menuangkan segala ide yang mereka miliki ke dalam bentuk tulisan serta merangkai kalimat demi kalimat menjadi sebuah teks yang utuh. 
Dengan penerapan model ini dalam pembelajaran, guru dapat meningkatkan hasil belajar siswa, hal tersebut terbukti dari hasil penelitian dan data yang diperoleh.

Pengaruh penggunaan Model Pembelajaran Peta Pikiran Terhadap Kemampuan Menulis Teks pidato Siswa Kelas IX SMP Negeri 17 Medan Tahun Pembelajaran 2016/2017. Sebagaimana disajikan pada hasil penelitian yang menunjukan nilai rata-rata untuk kemampuan menulis siswa pada tahap sebelum penerapan model peta pikira tergolong pada kategori cukup dengan nilai rata-rata 65,37 dibandingkan dengan tahap setelah diterapkan model peta pikiran yang berkategori baik dengan nilai rata-rata 81,09 Sehingga dari data tersebut dapat ditemukan bahwa model peta pikiran berpengaruh dalam meningkatkan kemampuan menulis teks pidato.

Berdasarkan hasil penelitian, data sebelum dan sesudah menggunakan model peta pikiran berdistribusi normal. Hal tersebut dapat dilihat dari uji normalitas data sebelum dan sesudah menggunakan model peta pikiran. Dari data homogenitas juga terbukti bahwa sampel penelitian ini berasal dari populasi yang homogen. Dan pengujian hipotesis telah membuktikan bahwa hipotesis alternatif (Ha) diterima. Dengan demikian model peta pikiran ini berpengaruh secara signifikan terhadap kemampuan menulis teks pidato siswa kelas IX SMP Negeri 17 Medan tahun pembelajaran 2016/2017.

\section{PENUTUP}

Berdasarkan hasil penelitian yang telah diuraikan pada pembahasan maka dapat diambil kesimpulan yaitu Kemampuan menulis teks pidato sebelum menggunakan model pembelajaran peta pikiran termasuk dalam tiga kategori, yaitu kategori baik sebanyak 13 siswa atau 40,62\%, dan dalam kategori cukup sebanyak 16 siswa atau 50\% dan kategori cukup sebanyak 3 siswa atau 9,37\%.

Kemampuan menulis teks pidato sesudah menggunakan model peta pikiran termasuk kategori sangat baik sebanyak 15 siswa atau 46,87\%, kategori baik sebanyak 15 siswa atau 46,87\%, dan dalam kategori cukup sebanyak 2 siswa atau $6,25 \%$. Berdasarkan pengujian hipotesis diketahui bahwa $t_{\text {hitung }}>t_{\text {tabel }}$ yakni 
6,26>2,04 dengan demikian hipotesis diterima. Hal ini membuktikan bahwa model pembelajaran peta pikiran berpengaruh terhadap kemampuan menulis.

\section{DAFTAR PUSTAKA}

Arikunto, Suharsimi. 2011. Prosedur Penelitian. Bandung :Rineka Cipta.

Departemen Pendidikan Nasional. 2007. Kamus Besar Bahasa Indonesia. Jakarta: Balai Pustaka.

DePorter. 2014. Quantum Teaching. Bandung : Kaifa

Emzir. 2007. Metodologi Penelitian Pendidikan. Jakarta : Rajawali Press

Arifin. 2013. Pengaruh Model Pembelajaran Mind Mapping Terhadap Kemampuan Menulis Teks Pidato Kelas XI MAN 1 Tanjung Pura Tahun Pembelajaran 2013/2014. Medan:Unimed

Ikhwanuddin, Muhammad. 2013. Penerapan Metode Mind Mapping Untuk Meningkatkan Keterampilan Menulis Karangan Narasi Pada Siswa Kelas IVA SDN Wonosari 02 Semarang 2013. Semarang:Universitas Negeri Semarang.

Kartindari. 2013. Kemampuan siswa kelas VIIIB SMP Muhammadiyah Jambi dalam Bermain drama. Jambi: Jurnal pendidikan bahasa Indonesia.

Kosasih. 2011. Ketatabahasan dan Kesusastraan. Bandung: Yrama Widya.

Ngalimun. 2014. Strategi dan Model Pembelajaran. Yogyakarta : Aswaja.

Saleh, Andri. 2008. Kreatif Mengajar dengan Mindmap. Bandung: Tinta Emas Publishing. 